medRxiv preprint doi: https://doi.org/10.1101/2020.04.29.20080234; this version posted June 25, 2020. The copyright holder for this preprint (which was not certified by peer review) is the author/funder, who has granted medRxiv a license to display the preprint in perpetuity. It is made available under a CC-BY-NC-ND 4.0 International license.

\title{
Hippocampal Avoidance Whole-brain Radiotherapy in Preservation of \\ Neurocognitive Function for Brain Metastases: A Phase II Blinded Randomized
}

\section{Trial}

Short Title: Blinded Randomized Trial for Hippocampal Avoidance WBRT

Wen-Chi Yang, M.D. ${ }^{1,4,5}$, Ya-Fang Chen, M.D. ${ }^{2.3}$, Chi-Cheng Yang, Ph.D. ${ }^{6}$, Pei-Fang

Wu, M.D. ${ }^{1}$, Hsing-Min Chan, M.S. ${ }^{1}$, Jenny Ling-Yu Chen, M.D., Ph.D. ${ }^{1,2}$, Guann-

Yiing Chen, M.D. ${ }^{1,3}$, Jason Chia-Hsien Cheng, M.D., Ph.D. ${ }^{1,4,5}$, Sung-Hsin Kuo, M.D., Ph.D. ${ }^{1,4,5}$, Feng-Ming Hsu, M.D., Ph.D. ${ }^{1,4,5}$

${ }^{1}$ Division of Radiation Oncology, Departments of Oncology, National Taiwan University Hospital, Taipei, Taiwan

${ }^{2}$ Department of Medical Imaging, National Taiwan University Hospital, Taipei, Taiwan ${ }^{3}$ Department of Medical Imaging, National Taiwan University Hospital Hsinchu branch,

Hsinchu, Taiwan

${ }^{4}$ Graduate Institute of Oncology, and ${ }^{5}$ Cancer Research Center, National Taiwan

University College of Medicine, Taipei, Taiwan

${ }^{6}$ Department of Psychology, National Chengchi University, Taipei, Taiwan NOTE: This preprint reports new research that has not been certified by peer review and should not be used to guide clinical practice. 
medRxiv preprint doi: https://doi.org/10.1101/2020.04.29.20080234; this version posted June 25, 2020. The copyright holder for this preprint

(which was not certified by peer review) is the author/funder, who has granted medRxiv a license to display the preprint in perpetuity.

It is made available under a CC-BY-NC-ND 4.0 International license .

Corresponding author: Feng-Ming Hsu, M.D., Ph.D.,

Division of Radiation Oncology, Department of Oncology,

National Taiwan University Hospital,

No. 7, Chung-Shan South Rd., Taipei, Taiwan; Phone: +886-2-23123456, ext. 62643

E-mail: hsufengming@ntuh.gov.tw

\section{Funding}

This work was partially supported by the National Taiwan University Hospital,

Yunlin Branch, Yunlin, Taiwan (NTUHYL 108.S004 to Wen-Chi Yang) and the

Ministry of Science and Technology, Executive Yuan, Taipei, Taiwan (MOST 107-

2314-B-002 -098 to Feng-Ming Hsu).

Disclosures: All authors have no conflicts of interest to disclose

Prior presentation: This work was presented as an oral abstract at the ASTRO $61^{\text {st }}$

annual meeting, September 15-18, 2019 in Chicago, IL 


\begin{abstract}
Background

Hippocampal avoidance whole-brain radiotherapy (HA-WBRT) shows potential for neurocognitive preservation. This study aimed to evaluate whether HA-WBRT or conformal WBRT is better for preserving neurocognitive function.
\end{abstract}

\title{
Methods
}

This single-blinded randomized phase II trial enrolled patients with brain metastases and randomly assigned to receive HA-WBRT or conformal WBRT. Primary end point is the decline of Hopkins Verbal Learning Test-Revised (HVLT-R) Delayed Recall at 4 months after treatment. Neurocognitive function tests were analyzed with a mixed effect model. Brain progression free survival (BPFS) and overall survival (OS) were estimated using the Kaplan-Meier method.

\section{Results}

Patients were enrolled from March 2015 to December 2018 with a median followup of 12.4 months. A total of 70 patients were randomized. No differences in baseline neurocognitive function existed between the two arms. There were no differences in any neurocognitive assessments at four months. At six months, patients receiving HAWBRT showed favorable perpetuation of HVLT-R total recall (mean difference $=2.60$, $p=0.079)$ and significantly better preservation of the HVLT-R recognition- 
medRxiv preprint doi: https://doi.org/10.1101/2020.04.29.20080234; this version posted June 25, 2020. The copyright holder for this preprint (which was not certified by peer review) is the author/funder, who has granted medRxiv a license to display the preprint in perpetuity.

It is made available under a CC-BY-NC-ND 4.0 International license .

discrimination index (mean difference $=1.78, p=0.019)$ and memory score (mean

difference $=4.38, p=0.020)$ compared with patients undergoing conformal WBRT.

There were no differences in TMT part A, part B, or the COWA test between the two arms at any time point. There were no differences in BPFS or OS between arms as well.

\section{Conclusions}

Patients receiving HA-WBRT without Memantine showed better preservation in late verbal memory, but not in verbal fluency or executive function.

Key words: Brain metastasis, Hippocampus, Whole brain radiotherapy,

Neuropsychological tests, Radiation effect, Single blind method 
medRxiv preprint doi: https://doi.org/10.1101/2020.04.29.20080234; this version posted June 25, 2020. The copyright holder for this preprint

\section{Introduction}

Brain metastases are the most common brain tumors in adults. A total of $10 \%-$

$30 \%$ of cancer patients develop brain metastases during the course of their illness[1].

Its incidence continues to increase with advances in diagnostic modalities, effective

systemic therapies, and improved survival of cancer patients[1, 2$]$.

Historically, brain metastasis patients show poor survival, with a median of one

month if left untreated and 3-6 months[3, 4] after treatment. Over several decades,

whole brain radiotherapy (WBRT) has become the standard of care for treating brain

metastasis[5], with an estimated response rate of $27 \%-56 \%[6,7]$. Several prognostic

models have been developed to predict clinical outcomes. The recursive partitioning

analysis (RPA)[8] proposed by the Radiation Therapy Oncology Group (RTOG) has

been the most widely used. Recently, the Graded Prognostic Assessment (GPA)

became the most common index for assessing brain metastasis outcomes[9]. Patients

with a good prognostic score from either index have a predicted overall survival of

around one year. Some specific subgroups of patients, such as oncogenes-driven lung

cancer or luminal-A breast cancer, can show an estimated survival of around two

years[10].

Despite improved survival in certain patients with brain metastasis, the toxicity of

brain irradiation raises concerns. Late effects of WBRT generally appear $\geq 3$ months 
medRxiv preprint doi: https://doi.org/10.1101/2020.04.29.20080234; this version posted June 25, 2020. The copyright holder for this preprint

after irradiation and could be irreversible and progressive; it is considered secondary to vascular injury, demyelination, and ultimately necrosis[11]. Symptoms range from mild lassitude to progressive memory loss and dementia[12-14]. The hippocampus is a known neurogenesis region[15] in adults, and brain irradiation causes hippocampal dysfunction, which results in memory defects and depression-like behavior[16].

Radiation dose and volume to the hippocampus can correlate with memory deficit[17].

Improved novel radiotherapy techniques make it possible to avoid the hippocampus while treating the entire brain[18, 19].

RTOG 0933 is a single-arm prospective phase II trial to evaluate the effect of hippocampus avoidance WBRT (HA-WBRT) on neurocognitive function[20]. It demonstrated the potential value in neurocognitive preservation of HA-WBRT using the Hopkins Verbal Learning Test-Revised (HVLT-R) tests. The HVLT-R-delayed recall decline at four months from baseline was reduced to $7 \%$ compared with $30 \%$ decline in historical control[21]. Here, we present a single-blinded, phase II randomized trial to compare neurocognitive function outcomes in patients with brain metastasis treated by either HA-WBRT or conformal WBRT. 
medRxiv preprint doi: https://doi.org/10.1101/2020.04.29.20080234; this version posted June 25, 2020. The copyright holder for this preprint

\section{Methods}

This study was approved by the institutional research ethics committee and was

independently monitored by the institutional clinical trial center. Informed consent was obtained from each patient in written form. This randomized trial is registered in ClinicalTrials.gov with identifier (NCT number): NCT02393131.

\section{Study design and participants}

Patients with histologically-proved non-hematological malignancy and

radiographic evidence of brain metastasis outside a $5 \mathrm{~mm}$ margin around either

hippocampus on gadolinium contrast-enhanced MRI obtained within 30 days prior to registration were eligible. Eligibility criteria included age 20 years or older, Karnofsky Performance Status $\geq 60$, and life expectancy of at least 4 months. Patients with the following conditions were excluded: prior brain radiotherapy or radiosurgery to $>5$ intracranial metastatic lesions or a biological-equivalent dose in 2-Gy fractions $>7.3$ Gy to $40 \%$ of the volume of bilateral hippocampus from prior radiosurgery ${ }^{[22]}$. Other exclusion criteria included serum creatinine $>2.0 \mathrm{mg} / \mathrm{dL}$ within 30 days prior to registration, leptomeningeal seeding, contraindication to MR imaging, and severe active comorbidities as judged by investigators. Patients were not allowed to receive investigational systemic therapy during WBRT. Patients who met all eligibility criteria 
medRxiv preprint doi: https://doi.org/10.1101/2020.04.29.20080234; this version posted June 25, 2020. The copyright holder for this preprint

(which was not certified by peer review) is the author/funder, who has granted medRxiv a license to display the preprint in perpetuity.

It is made available under a CC-BY-NC-ND 4.0 International license.

were randomly assigned to receive either hippocampus avoidance WBRT (HA-WBRT)

or conformal WBRT.

\section{$\underline{\text { Treatments }}$}

The WBRT treatment was 3 Gy per fraction once per workday for continuous

workdays (Monday to Friday) every week for 10 days, to a total dose of $30 \mathrm{~Gy}$. A non-

contrast treatment-planning CT scan of the entire head region was required to define

planning target volumes and hippocampal avoidance zones. The pre-treatment brain

MRI was fused semi-automatically with treatment-planning CT for hippocampal

contouring. Contouring was carried out in accordance with the Radiation Therapy

Oncology Group (RTOG) atlas based on RTOG 0933[20] with the assistance of

experienced neuroradiologists. Treatment plans were designed with volumetric

modulated arc therapy (VMAT or RapidArc) using 6MV photon for both HA-WBRT

and conformal WBRT arms. Dosimetry criteria for radiotherapy planning are described

in the Supplementary Material. Treatment was delivered with daily image guidance

using online cone beam $\mathrm{CT}$ for $3 \mathrm{D}$ corrections. 
medRxiv preprint doi: https://doi.org/10.1101/2020.04.29.20080234; this version posted June 25, 2020. The copyright holder for this preprint (which was not certified by peer review) is the author/funder, who has granted medRxiv a license to display the preprint in perpetuity.

\section{$\underline{\text { Assessment }}$}

All patients were evaluated at entry, during treatment, and after treatment at 1,2,

4, and 6 months, then every 3 months until death or brain progression. Adverse events

were graded according to the National Cancer Institute's common toxicity criteria

(CTCAE), version 4.

Neurocognitive function tests, self-reported neurocognitive function, and self-

reported health-related quality of life were assessed at base line, at 1, 2, 4, 6 months,

followed by every 3 months up to 24 months after WBRT unless brain progression or

death occurred. The neuropsychological test battery included tests of memory,

processing speed, executive function, and verbal fluency. Hopkins Verbal Learning

Test-Revised (HVLT-R), Trail Making Test Part A(TMT-A), Trail Making Test Part B

(TMT-B), and Controlled Oral Word Association (COWA) were conducted by blinded

independent health professionals and data were recorded as raw scores, time, and word

counts without normalization. Self-reported cognitive outcomes were assessed using

the EORTC QLQ-C30, and FACT-Cog version 3. We assessed self-reported health-

related quality of life specific to brain metastasis using the EORTC QLQ-BN20. All

tests and questionnaires used were Traditional Mandarin versions and certified by a

board-certified neurologist and psychologist. 
medRxiv preprint doi: https://doi.org/10.1101/2020.04.29.20080234; this version posted June 25, 2020. The copyright holder for this preprint (which was not certified by peer review) is the author/funder, who has granted medRxiv a license to display the preprint in perpetuity.

It is made available under a CC-BY-NC-ND 4.0 International license .

Gadolinium contrast-enhanced MRI was used to assess intracranial failure and

obtained prior to treatment and at 4, 9, and 12 months after WBRT until intracranial disease progression, upon new onset of neurological signs, or upon symptoms suggestive of progressive brain metastasis.

\section{$\underline{\text { Statistical analysis }}$}

We conducted a single-blinded randomized trial with a randomization ratio of 1:1.

The actual treatment given to individual patients was determined by randomization with permuted-block design stratified by prior cranial radiosurgery. The primary endpoint was neurocognitive function as determined by a decline in HVLT-R delayed recall score from baseline to 4 months after WBRT. Previous results of standard conventional WBRT resulted in a 40\% mean decline in cognitive loss at 3 to 6 months[21]. We hypothesized that using conformal WBRT with or without hippocampal avoidance would reduce the decline from baseline to $20 \%$ at 4 months. A Simon's randomized phase II design was used to calculate sample size[23]. We required 42 evaluable subjects (21 in the HA-WBRT group and 21 in the conformal WBRT group) for a $90 \%$ probability of correctly selecting the best intervention group. We anticipated that up to $35 \%$ of patients would drop out prior to the 4-month assessment and would not be included in the final analysis. The target sample size was 
medRxiv preprint doi: https://doi.org/10.1101/2020.04.29.20080234; this version posted June 25, 2020. The copyright holder for this preprint (which was not certified by peer review) is the author/funder, who has granted medRxiv a license to display the preprint in perpetuity.

It is made available under a CC-BY-NC-ND 4.0 International license .

64 registered subjects. Neurocognitive failure was defined as a drop in raw scores from

baseline more than 2 standard deviations (SD) for any HVLT-R category (Total Recall,

Delayed Recall, and Recognition Index).

Secondary endpoints included self-reported cognitive functioning, health-related

quality of life, progression of brain metastasis, overall survival, and acute or late

treatment related toxicity. Intracranial progression was defined as radiographic

evidence of enlarged brain tumor according to RECIST 1.1 criteria or confirmed

leptomeningeal seeding from cerebral spinal fluid studies. Brain progression free

survival (BPFS) was calculated from randomization until brain progression or death.

Hippocampal failure was documented and defined as the presence of new brain

metastasis within a $5 \mathrm{~mm}$ margin around either hippocampus. Overall survival (OS)

was defined as time from randomization to death. Self-reported cognitive functioning

and health-related quality of life are under analysis and not reported in this article.

Descriptive data were reported and compared between the two arms. An

independent t-test for continuous variables and Chi-square or Fisher's exact test were

performed for categorical variable comparison. A mixed effect model was used for

neurocognitive function tests to assess the time effects within patients during serial

follow-up and the hippocampus avoidance effect between the two arms. Survival was

estimated using the Kaplan-Meier method and differences between patients or 
medRxiv preprint doi: https://doi.org/10.1101/2020.04.29.20080234; this version posted June 25, 2020. The copyright holder for this preprint (which was not certified by peer review) is the author/funder, who has granted medRxiv a license to display the preprint in perpetuity.

It is made available under a CC-BY-NC-ND 4.0 International license .

treatment characteristics were assessed using log-rank tests. A two-sided p-value of

less than 0.05 was considered statistically significant. Statistical analyses were

performed using GraphPad Prism 8.31 (GraphPad Software Inc.). 
medRxiv preprint doi: https://doi.org/10.1101/2020.04.29.20080234; this version posted June 25,2020 . The copyright holder for this preprint

\section{Results}

\section{$\underline{\text { Patient characteristics }}$}

From March 2015 to December 2018, we enrolled 70 eligible and evaluated 65

analyzable patients. The CONSORT diagram is shown in Figure 1. The median

follow-up time for all evaluated patients was 12.4 months (range: 0.9 to 54.8 months).

Patient characteristics are summarized in Table 1. There were no significant

differences between the two arms in terms of age, performance status, GPA, and

education level, except that more patients in the HA-WBRT arm had prior brain

surgery. The representative radiotherapy plans are shown in Supplementary Figure S1

and Figure S2. Despite equivalent prescription dose, patients in the HA-WBRT group

received a higher integral dose compared to those in the conformal WBRT group

(1158.6 MUs vs. 727.6 MUs, $p<0.001)$.

\section{Adverse events}

Overall, $90.1 \%$ of patients in the HA-WBRT arm and $87.5 \%$ of patients in the conformal WBRT arm experienced some grade of toxicity. The most common toxicities were nausea (36 patients), fatigue (36 patients), vomiting (27 patients), and dizziness (9 patients). A non-significantly higher grade 2 toxicity rate was noticed in the HA-WART arm $(60.6 \%$ vs. $46.9 \%, p=0.74)$. One patient in each arm experienced 
medRxiv preprint doi: https://doi.org/10.1101/2020.04.29.20080234; this version posted June 25,2020 . The copyright holder for this preprint

complications with grade 3 toxicity after WBRT. One had progressive brain lesions

during WBRT and received a craniotomy, while the other had severe symptomatic

cerebral edema, which was resolved following bevacizumab and steroid treatment. No

patients experienced grade 4 or 5 toxicity.

\section{$\underline{\text { Neurocognitive outcomes }}$}

All tests were performed using the Traditional Mandarin version. There were no

differences in baseline neurocognitive functions between arms as shown in Table 2 .

The 4-month follow-up showed an average of $-8.8 \%$ and $+3.8 \%$ percentage change in

HVLT-R delayed recall from baseline in the HA-WBRT arm and conformal WBRT

arm, respectively. Both were better than expected and without significant differences ( $p$

$=0.31)$. Overall, there were no differences in any neurocognitive assessments between

the two arms at the 4-month follow-up (Table 2).

By analyzing all neurocognitive function tests for all time-points, we found a significant perpetuation of neurocognitive function in the HVLT-R recognition index (mean difference $=1.78,95 \%$ confidence interval: 0.31 to $3.25, p=0.019$ ) and a trend of preservation in HVLT-R total recall (mean difference $=2.60,95 \%$ confidence interval: -0.32 to $5.52, p=0.079$ ) at the 6-month follow-up in the HA-WBRT arm

(Figure 2 and Table 2). By using the memory score[24] (the sum of HVTL-R total 
medRxiv preprint doi: https://doi.org/10.1101/2020.04.29.20080234; this version posted June 25,2020 . The copyright holder for this preprint

(which was not certified by peer review) is the author/funder, who has granted medRxiv a license to display the preprint in perpetuity.

It is made available under a CC-BY-NC-ND 4.0 International license.

recall and recognition index), the preservation of verbal learning and memory was significantly superior in the HA-WBRT arm at 6-month follow-up (mean difference $=$ $4.38,95 \%$ confidence interval: 0.72 to $8.03, p=0.020$ ), and in favor of the HA-WBRT arm thereafter till the completion of follow-up at 24 months (Figure 2). Despite a lack of significant differences in HVLT-R delayed recall, TMT-A, TMT-B, or COWA tests at any time points, patients receiving HA-WBRT outperformed in all aspects of the neurocognitive function tests at the 6-month follow-up (Table 2). There was also no difference in cumulative incidence of neurocognitive failure between the two arms after adjusting competing risks (Gray's test $p=0.93$, Supplementary Figure S3). The 4- and 6-month cumulative incidence of neurocognitive failure was $15.2 \%$ and $18.2 \%$ in the HA-WBRT arm and $12.5 \%$ and $15.6 \%$ in the conformal WBRT arm, respectively.

\section{$\underline{\text { Intracranial progression and survival }}$}

The median OS was 13.3 months for patients in the HA-WBRT arm and 15.0 months in the conformal WBRT arm (Hazard ratio $=1.32,95 \%$ confidence interval: 0.73 to $2.38, p=0.355)$. No significant differences in BPFS existed between the HAWBRT and conformal WBRT arms (Hazard ratio $=1.17,95 \%$ confidence interval: 0.69 to $1.98, p=0.557)$. Figure 3 shows survival curves for OS and BPFS. Adjusting the 
medRxiv preprint doi: https://doi.org/10.1101/2020.04.29.20080234; this version posted June 25, 2020. The copyright holder for this preprint (which was not certified by peer review) is the author/funder, who has granted medRxiv a license to display the preprint in perpetuity.

It is made available under a CC-BY-NC-ND 4.0 International license .

competing risk showed that there was also no difference in cumulative incidence for

intracranial failure (Supplementary Figure S4). In total, four patients developed

hippocampal failures, of which three were assigned to intervention of hippocampal avoidance (crude incidence $9.1 \%$ ).

\section{Discussion}

This phase II randomized trial compared the effectiveness of HA-WBRT and conformal WBRT in neurocognitive function preservation. The results failed to demonstrate any benefit of hippocampal avoidance in neurocognitive preservation by HVLT-R delayed recall at four months after treatment. However, we observed a marginal benefit in perpetuation of HVLT-R total recall and significant protection in HVLT-R recognition index and memory score after HA-WBRT. To our knowledge, this is the first and only blinded randomized trial assessing the clinical benefit of hippocampal sparing performed in a non-English speaking Asian cohort.

A recently published phase III randomized study NRG-CC001[25], which was a multi-center, open label trial comparing hippocampal avoidance WBRT to conventional opposing-fields WBRT together with Memantine use, demonstrated that HA-WBRT with Memantine showed significantly lower risk of neurocognitive failure (adjusted hazard ratio, $0.74 ; p=0.02$ ). Further, patients in the HA-WBRT arm showed 
medRxiv preprint doi: https://doi.org/10.1101/2020.04.29.20080234; this version posted June 25, 2020. The copyright holder for this preprint (which was not certified by peer review) is the author/funder, who has granted medRxiv a license to display the preprint in perpetuity.

It is made available under a CC-BY-NC-ND 4.0 International license .

less deterioration of executive function at four months $(p=0.01)$ and learning memory at six months $(p=0.02)$. In our trial, we also found less deterioration in verbal memory by HVLT-R total recall $(p=0.079)$ and HVLT-R recognition index $(p=0.019)$ at six months after WBRT. Memory score[24], which was reported to have higher sensitivity than HVLT-R total recall in detecting dementia, was also less declined in patients receiving HA-WBRT at 6 months $(p=0.020)$ and preferably preserved with longer follow-up (though non-significant). In contrast, no differences in executive function were noticed. The clinical impact of HA-WBRT seemed to be less beneficial in our study than in the NRG trial. There were some differences in trial design, which may have influenced neurocognitive outcomes.

The present study was a blinded randomized trial. Although only patients and not investigators were blinded to treatment arms, our trial could be considered a doubleblind randomized trial since the neurocognitive functions were assessed independently by trained health professionals with no knowledge of the patients' assigned group. The patient's expectation may have some placebo or psychotherapeutic effects on neurocognitive outcomes. Open-label placebo effects are discussed extensively in the neurologic and psychiatric fields[26, 27]. Studies addressing the placebo effect on neurocognitive function have been consistently presented in various diseases, such as traumatic brain injury or Alzheimer's disease[28, 29]. The neurobiological basis 
medRxiv preprint doi: https://doi.org/10.1101/2020.04.29.20080234; this version posted June 25, 2020. The copyright holder for this preprint (which was not certified by peer review) is the author/funder, who has granted medRxiv a license to display the preprint in perpetuity.

It is made available under a CC-BY-NC-ND 4.0 International license .

mainly involves a brain-rewarding system, where cognitive and affective functions,

including awareness, insight, expectation modulation, learning, and memory, all

contributed[29]. The placebo effect is also evident when treating cognitive function

after radiation-induced brain injury[30].

In our comparison arm, we chose conformal WBRT rather than traditional bilateral opposing-fields WBRT. The conformal WBRT was delivered using VMAT or

RapidArc techniques. The procedures for radiotherapy delivery were identical for patients in both arms, which makes the blindness more reliable. Further, conformal WBRT provided a dose distribution similar to the HA-WBRT compared with bilateral opposing-fields WBRT (Supplementary Figure S2). We assumed that the bias of acute toxicity to normal tissues other than the hippocampus could be minimized. The blinded testers and placebo/psychotherapeutic effects of conformal WBRT may be one reason why the difference between intervention arms was trivial in the present trial.

Memantine, a NMDA receptor antagonist, is effective in neuroprotection when in concurrent and adjuvant use with WBRT[31]. Despite its proven efficacy, the drug is not widely prescribed during WBRT in the U.S.[32]. Only $11 \%$ of radiation oncologists in the survey considered Memantine for use, with less than $10 \%$ of their patients.

Memantine was also not widely used in our society and not reimbursed by the health care system when developing the present clinical trial. Recent preclinical data revealed 
medRxiv preprint doi: https://doi.org/10.1101/2020.04.29.20080234; this version posted June 25, 2020. The copyright holder for this preprint (which was not certified by peer review) is the author/funder, who has granted medRxiv a license to display the preprint in perpetuity.

It is made available under a CC-BY-NC-ND 4.0 International license .

that Memantine may protect against radiation injury. Duman et al.[33] discovered remodeling of the hippocampal excitatory synapse following radiation treatment. Preadministration of Memantine can revert this radiation-induced phenomenon. This interaction may imply a synergistic effect in neuroprotection from simultaneous use of HA-WBRT and Memantine. The lack of Memantine use in the present study may be another reason why patients in our cohort benefited less from HA-WBRT than those in the NRG-CC001 trial.

Importantly, current available evidence for HA-WBRT was mainly from Western countries such as the United States, especially for English-speaking cohorts. Despite these neurocognitive function tests in the neuropychiatric fields being translated into other languages, including Chinese Mandarin with validation reports[34], it is uncommon in clinical oncology trials in Asia. Effectively evaluating neurocognitive function preservation with a language barrier raises concerns. A dosimetry study of HA-WBRT showed dose volume of the irradiated hippocampus correlated well with neurocognitive function using word list learning tests in the Mandarin version[35]. They also reported no significant deterioration in memory function after HA-WBRT for patients with brain oligo-metastases or prophylactic cranial irradiation in a single arm phase II trial[36]. Our study is the first randomized trial evaluating HA-WBRT in a Mandarin-speaking cohort. The major results are in accordance with the NRG- 
medRxiv preprint doi: https://doi.org/10.1101/2020.04.29.20080234; this version posted June 25, 2020. The copyright holder for this preprint

CC001 trial, which will help reinforce the confidence of radiation oncologists in

Mandarin-speaking areas to treat suitable patients with highly complex and time-

consuming HA-WBRT techniques[18].

The limitations in our trial include a small patient number, unconventional phase II design, and a single institutional study. Despite those limitations, more than three quarters and half of enrolled patients followed and completed the protocol tests at 4month and 6-month follow-ups after WBRT, respectively. The blinded testers and testees, as well as the high compliance rate of the present study, greatly reduced biases and make our results more reliable.

Combing the NRG-CC001 and present trial, both studies demonstrated that preserved verbal memory measured by HVLT-R was more prominent at 6-month rather than 4-month follow-up after HA-WBRT. This is compatible with previous clinical observations[37] and pre-clinical studies of hippocampal dysfunction[16]. Long-term follow-ups later than six months may be more appropriate to evaluate effects on verbal memory function following radiation treatment. This also suggests good-prognostic patients are more likely to benefit from HA-WBRT. Future trials should adapt late time points to determine neurocognitive outcomes.

\section{Conclusions}

Patients receiving hippocampus-avoidant conformal WBRT without Memantine 
medRxiv preprint doi: https://doi.org/10.1101/2020.04.29.20080234; this version posted June 25, 2020. The copyright holder for this preprint (which was not certified by peer review) is the author/funder, who has granted medRxiv a license to display the preprint in perpetuity. It is made available under a CC-BY-NC-ND 4.0 International license .

for brain metastases show better preservation of late verbal memory, but not of verbal fluency or executive function. Placebo or psychotherapeutic effects may contribute to unexpected favorable neurocognitive outcomes after conformal WBRT. 
medRxiv preprint doi: https://doi.org/10.1101/2020.04.29.20080234; this version posted June 25, 2020. The copyright holder for this preprint (which was not certified by peer review) is the author/funder, who has granted medRxiv a license to display the preprint in perpetuity.

It is made available under a CC-BY-NC-ND 4.0 International license.

\section{Acknowledgments}

We appreciate the assistance of statistician Dr. Chin-Hao Chang, Ph.D. at the

Department of Medical Research, National Taiwan University Hospital, Taipei,

Taiwan, in trial design. We acknowledge the efforts of Chueh-Hui Lin, R.N. and Tsai-

Tsan $\mathrm{Wu}, \mathrm{R} . \mathrm{N}$. in trial management and data collection. We would like to thank

Anthony Abram at Uni-edit for editing and proofreading this manuscript. 
medRxiv preprint doi: https://doi.org/10.1101/2020.04.29.20080234; this version posted June 25, 2020. The copyright holder for this preprint (which was not certified by peer review) is the author/funder, who has granted medRxiv a license to display the preprint in perpetuity.

\section{References}

1. Barnholtz-Sloan JS, Sloan AE, Davis FG, et al. Incidence proportions of brain metastases in patients diagnosed (1973 to 2001) in the Metropolitan Detroit Cancer Surveillance System. J Clin Oncol 2004;22(14):2865-72.

2. Eichler AF, Chung E, Kodack DP, et al. The biology of brain metastases-translation to new therapies. Nat Rev Clin Oncol 2011;8(6):344-56.

3. Khuntia D, Brown $\mathrm{P}$, Li J, et al. Whole-brain radiotherapy in the management of brain metastasis. J Clin Oncol 2006;24(8):1295-304.

4. Zimm S, Wampler GL, Stablein D, et al. Intracerebral metastases in solid-tumor patients: natural history and results of treatment. Cancer 1981;48(2):384-94.

5. Chao JH, Phillips R, Nickson JJ. Roentgen-ray therapy of cerebral metastases. Cancer 1954;7(4):682-9.

6. Pease NJ, Edwards A, Moss LJ. Effectiveness of whole brain radiotherapy in the treatment of brain metastases: a systematic review. Palliat Med 2005;19(4):288-99.

7. van der Steen-Banasik E, Hermans J, Tjho-Heslinga R, et al. The objective response of brain metastases on radiotherapy. A prospective study using computer tomography. Acta Oncol 1992;31(7):777-80.

8. Gaspar L, Scott C, Rotman M, et al. Recursive partitioning analysis (RPA) of prognostic factors in three Radiation Therapy Oncology Group (RTOG) brain metastases trials. Int J Radiat Oncol Biol Phys 1997;37(4):745-51.

9. Sperduto PW, Berkey B, Gaspar LE, et al. A new prognostic index and comparison to three other indices for patients with brain metastases: an analysis of 1,960 patients in the RTOG database. Int J Radiat Oncol Biol Phys 2008;70(2):510-4.

10. Sperduto PW, Kased N, Roberge D, et al. Summary report on the graded prognostic assessment: an accurate and facile diagnosis-specific tool to estimate survival for patients with brain metastases. J Clin Oncol 2012;30(4):419-25. 
medRxiv preprint doi: https://doi.org/10.1101/2020.04.29.20080234; this version posted June 25, 2020. The copyright holder for this preprint (which was not certified by peer review) is the author/funder, who has granted medRxiv a license to display the preprint in perpetuity. It is made available under a CC-BY-NC-ND 4.0 International license .

11. Greene-Schloesser D, Moore E, Robbins ME. Molecular pathways: radiationinduced cognitive impairment. Clin Cancer Res 2013;19(9):2294-300.

12. Laack NN, Brown PD. Cognitive sequelae of brain radiation in adults. Semin Oncol 2004;31(5):702-13.

13. Greene-Schloesser D, Robbins ME. Radiation-induced cognitive impairment--from bench to bedside. Neuro Oncol 2012;14 Suppl 4:iv37-44.

14. Saad S, Wang TJ. Neurocognitive Deficits After Radiation Therapy for Brain Malignancies. Am J Clin Oncol 2015;38(6):634-40.

15. Monje ML, Palmer T. Radiation injury and neurogenesis. Curr Opin Neurol 2003;16(2):129-34.

16. Son $\mathrm{Y}$, Yang $\mathrm{M}$, Wang $\mathrm{H}$, et al. Hippocampal dysfunctions caused by cranial irradiation: a review of the experimental evidence. Brain Behav Immun 2015;45:287-96. 17. Ma TM, Grimm J, McIntyre R, et al. A prospective evaluation of hippocampal radiation dose volume effects and memory deficits following cranial irradiation. Radiother Oncol 2017;125(2):234-240.

18. Gondi V, Tolakanahalli R, Mehta MP, et al. Hippocampal-sparing whole-brain radiotherapy: a "how-to" technique using helical tomotherapy and linear acceleratorbased intensity-modulated radiotherapy. Int J Radiat Oncol Biol Phys 2010;78(4):124452.

19. Gondi V, Tome WA, Mehta MP. Why avoid the hippocampus? A comprehensive review. Radiother Oncol 2010;97(3):370-6.

20. Gondi V, Pugh SL, Tome WA, et al. Preservation of memory with conformal avoidance of the hippocampal neural stem-cell compartment during whole-brain radiotherapy for brain metastases (RTOG 0933): a phase II multi-institutional trial. J Clin Oncol 2014;32(34):3810-6.

21. Meyers CA, Smith JA, Bezjak A, et al. Neurocognitive function and progression in 
medRxiv preprint doi: https://doi.org/10.1101/2020.04.29.20080234; this version posted June 25, 2020. The copyright holder for this preprint (which was not certified by peer review) is the author/funder, who has granted medRxiv a license to display the preprint in perpetuity.

It is made available under a CC-BY-NC-ND 4.0 International license .

patients with brain metastases treated with whole-brain radiation and motexafin gadolinium: results of a randomized phase III trial. J Clin Oncol 2004;22(1):157-65.

22. Gondi V, Hermann BP, Mehta MP, et al. Hippocampal dosimetry predicts neurocognitive function impairment after fractionated stereotactic radiotherapy for benign or low-grade adult brain tumors. Int J Radiat Oncol Biol Phys 2012;83(4):e48793.

23. Simon R, Wittes RE, Ellenberg SS. Randomized phase II clinical trials. Cancer Treat Rep 1985;69(12):1375-81.

24. Hogervorst E, Combrinck M, Lapuerta P, et al. The Hopkins Verbal Learning Test and screening for dementia. Dement Geriatr Cogn Disord 2002;13(1):13-20.

25. Brown PD, Gondi V, Pugh S, et al. Hippocampal Avoidance During Whole-Brain Radiotherapy Plus Memantine for Patients With Brain Metastases: Phase III Trial NRG Oncology CC001. J Clin Oncol 2020; 10.1200/jco.19.02767:Jco1902767.

26. Linde K, Witt CM, Streng A, et al. The impact of patient expectations on outcomes in four randomized controlled trials of acupuncture in patients with chronic pain. Pain 2007;128(3):264-71.

27. Diederich NJ, Goetz CG. The placebo treatments in neurosciences: New insights from clinical and neuroimaging studies. Neurology 2008;71(9):677-84.

28. Curie A, Yang K, Kirsch I, et al. Placebo Responses in Genetically Determined Intellectual Disability: A Meta-Analysis. PLoS One 2015;10(7):e0133316.

29. Polich G, Iaccarino MA, Kaptchuk TJ, et al. Placebo Effects in Traumatic Brain Injury. J Neurotrauma 2018;35(11):1205-1212.

30. Rapp SR, Case LD, Peiffer A, et al. Donepezil for Irradiated Brain Tumor Survivors: A Phase III Randomized Placebo-Controlled Clinical Trial. J Clin Oncol 2015;33(15):1653-9.

31. Brown PD, Pugh S, Laack NN, et al. Memantine for the prevention of cognitive 
medRxiv preprint doi: https://doi.org/10.1101/2020.04.29.20080234; this version posted June 25, 2020. The copyright holder for this preprint

dysfunction in patients receiving whole-brain radiotherapy: a randomized, double-blind, placebo-controlled trial. Neuro Oncol 2013;15(10):1429-37.

32. Slade AN, Stanic S. The impact of RTOG 0614 and RTOG 0933 trials in routine clinical practice: The US Survey of Utilization of Memantine and IMRT planning for hippocampus sparing in patients receiving whole brain radiotherapy for brain metastases. Contemp Clin Trials 2016;47:74-7.

33. Duman JG, Dinh J, Zhou W, et al. Memantine prevents acute radiation-induced toxicities at hippocampal excitatory synapses. Neuro Oncol 2018;20(5):655-665.

34. Liu CC, Hua MS, Hwang TJ, et al. Neurocognitive functioning of subjects with putative pre-psychotic states and early psychosis. Schizophr Res 2015;164(1-3):40-6.

35. Tsai PF, Yang CC, Chuang CC, et al. Hippocampal dosimetry correlates with the change in neurocognitive function after hippocampal sparing during whole brain radiotherapy: a prospective study. Radiat Oncol 2015;10:253.

36. Lin SY, Yang CC, Wu YM, et al. Evaluating the impact of hippocampal sparing during whole brain radiotherapy on neurocognitive functions: A preliminary report of a prospective phase II study. Biomed J 2015;38(5):439-49.

37. Greene-Schloesser D, Robbins ME, Peiffer AM, et al. Radiation-induced brain injury: A review. Front Oncol 2012;2:73. 
medRxiv preprint doi: https://doi.org/10.1101/2020.04.29.20080234; this version posted June 25, 2020. The copyright holder for this preprint (which was not certified by peer review) is the author/funder, who has granted medRxiv a license to display the preprint in perpetuity. It is made available under a CC-BY-NC-ND 4.0 International license .

Figure 1. Consort flow diagram.

75 Assessed for eligibility

\begin{tabular}{|c|c|}
\hline & $\begin{array}{l}5 \text { Excluded for not meeting inclusion criteria } \\
2 \text { With leptomeningeal seeding } \\
1 \text { With estimated survival less than } 4 \text { months } \\
2 \text { With hippocampus involvement }\end{array}$ \\
\hline \multicolumn{2}{|c|}{70 Randomized } \\
\hline $\begin{array}{l}35 \text { Assigned to receive HA-WBRT } \\
33 \text { Complete HA-WBRT } \\
2 \text { Did not complete HA-WBRT } \\
\text { (one had cardiac metastases and could not cooperate with } \\
\text { treatment, the other died before WBRT due to disease } \\
\text { progression) }\end{array}$ & $\begin{array}{l}35 \text { Assigned to receive conformal WBRT } \\
32 \text { Complete conformal WBRT } \\
3 \text { Did not complete conformal WBRT } \\
\text { (one had malignant pericardial effusion and could not } \\
\text { cooperate with treatment, another died before WBRT } \\
\text { completed due to disease progression, and a third had } \\
\text { intracranial hemorrhage during WBRT and then received } \\
\text { craniotomy) }\end{array}$ \\
\hline $\begin{array}{l}33 \text { Included in analysis } \\
25 \text { At least } 4 \text { months NCF follow up }\end{array}$ & $\begin{array}{l}32 \text { Included in analysis } \\
24 \text { At least } 4 \text { months NCF follow up }\end{array}$ \\
\hline
\end{tabular}


medRxiv preprint doi: https://doi.org/10.1101/2020.04.29.20080234; this version posted June 25, 2020. The copyright holder for this preprint (which was not certified by peer review) is the author/funder, who has granted medRxiv a license to display the preprint in perpetuity.

It is made available under a CC-BY-NC-ND 4.0 International license .

Figure 2. Changes in raw scores of HVLT-R (A) memory score, the sum of (B) total recall and $(\mathrm{C})$ recognition Index from baseline between the hippocampal avoidancewhole brain radiotherapy (HA-WBRT) arm and the conformal WBRT arm. Data were plotted as mean values and $95 \%$ confidence intervals.

A HVLT-Memory Score

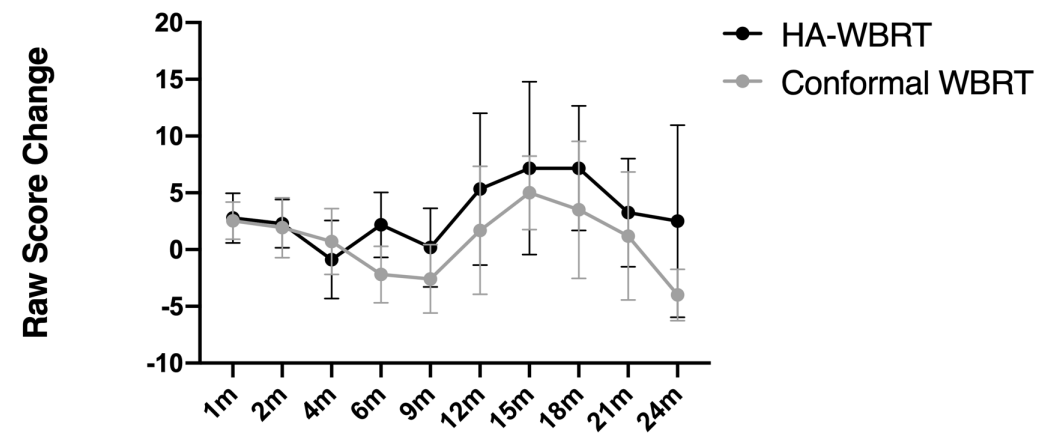

B HVLT-Total Recall

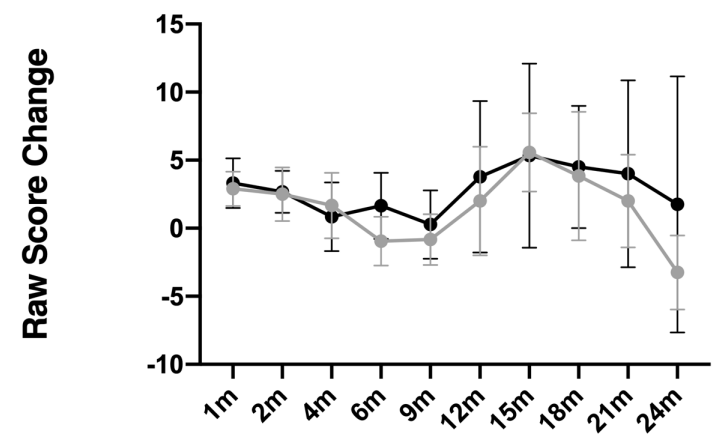

C HVLT-Recognition Index

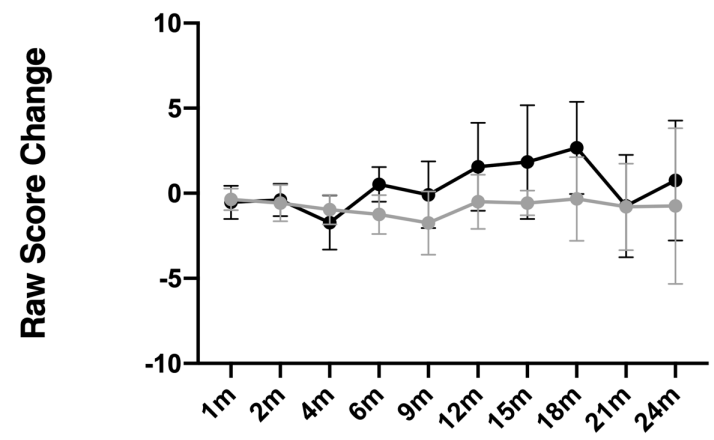

Follow Up Time (months) 
medRxiv preprint doi: https://doi.org/10.1101/2020.04.29.20080234; this version posted June 25, 2020. The copyright holder for this preprint (which was not certified by peer review) is the author/funder, who has granted medRxiv a license to display the preprint in perpetuity.

It is made available under a CC-BY-NC-ND 4.0 International license .

Figure 3. Kaplan-Meier survival curves of (A) overall survival and (B) brain

progression free survival for analyzable patients between the hippocampal avoidance-

whole brain radiotherapy (HA-WBRT) arm and the conformal WBRT arm.
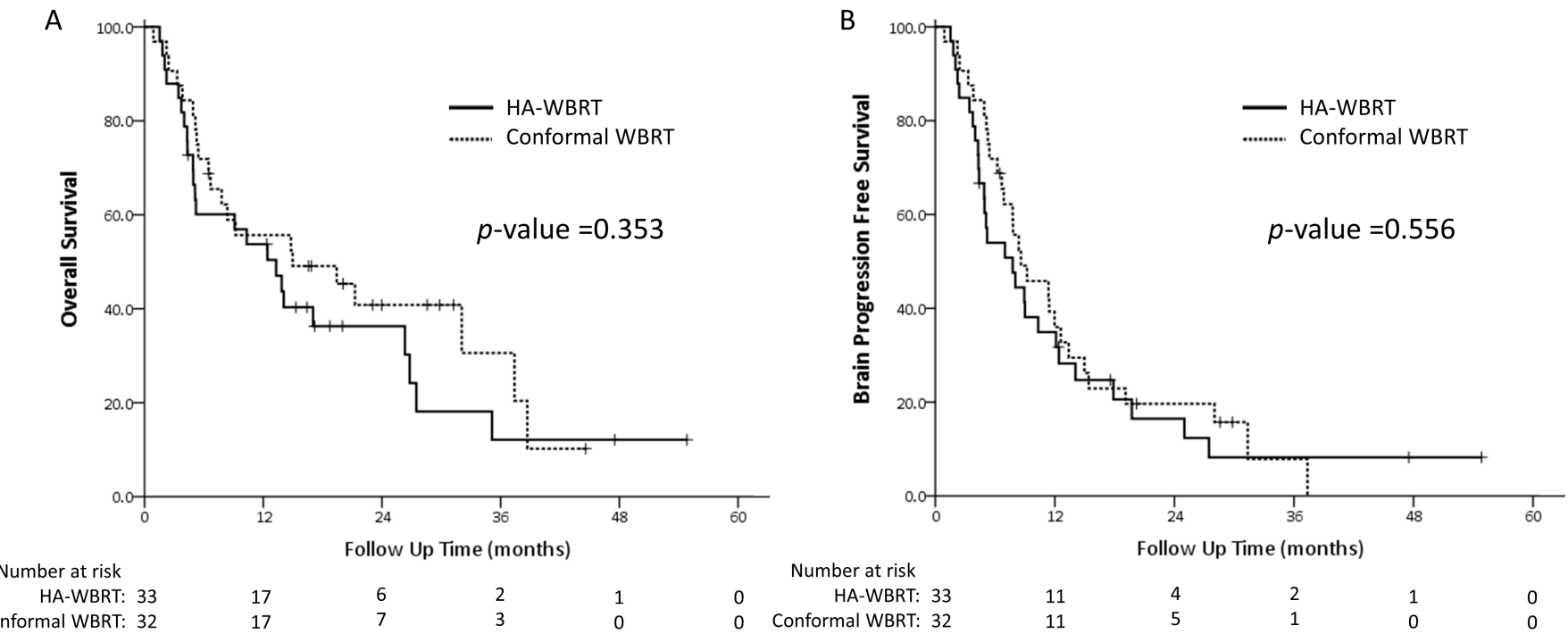
medRxiv preprint doi: https://doi.org/10.1101/2020.04.29.20080234; this version posted June 25 , 2020. The copyright holder for this preprint (which was not certified by peer review) is the author/funder, who has granted medRxiv a license to display the preprint in perpetuity.

It is made available under a CC-BY-NC-ND 4.0 International license.

Table 1. Patient characteristics

\begin{tabular}{|c|c|c|c|}
\hline & HA-WBRT $(N=33)$ & Conformal WBRT $(N=32)$ & $p$-value \\
\hline Age (mean years old) & 58.4 & 58.3 & 0.977 \\
\hline \multirow[t]{2}{*}{ Gender } & Male $42.4 \%$ (14) & Male $40.6 \%$ (13) & 0.883 \\
\hline & Female $57.6 \%$ (19) & Female $59.4 \%$ (19) & \\
\hline KPS (median) & 90 & 90 & 0.988 \\
\hline GPA (median) & 1.5 & 1.25 & 0.656 \\
\hline Pre-treatment & None: $69.7 \%$ (23) & None: $75 \%(24)$ & 0.633 \\
\hline neurological symptoms & Minor: 30.3\% (10) & Minor: $25 \%(9)$ & \\
\hline \multirow[t]{3}{*}{ Primary cancer } & Lung: 97.0\% (32) & Lung: 90.6\% (29) & 0.331 \\
\hline & Breast: $0 \%(0)$ & Breast: $6.2 \%(2)$ & \\
\hline & Others: $3.0 \%(33)$ & Others: $3.1 \%(1)$ & \\
\hline High educated (High school) & $84.8 \%(28)$ & $84.4 \%(27)$ & 0.958 \\
\hline Prior brain surgery & $15.2 \%(5)$ & $3.1 \%(1)$ & 0.105 \\
\hline Prior cranial SRS & $9.1 \%(3)$ & $9.4 \%(3)$ & 0.649 \\
\hline Brain only metastasis & $21.2 \%(7)$ & $21.9 \%(7)$ & 0.948 \\
\hline
\end{tabular}

Abbreviations: $N$, numbers; HA-WBRT, hippocampal avoidance whole brain radiotherapy; WBRT, whole brain radiotherapy; KPS, Karnofsky Performance Score; GPA, Graded Prognostic Assessment in brain metastases; SRS, stereotactic radiosurgery. 
medRxiv preprint doi: https://doi.org/10.1101/2020.04.29.20080234; this version posted June 25, 2020. The copyright holder for this preprint (which was not certified by peer review) is the author/funder, who has granted medRxiv a license to display the preprint in perpetuity. It is made available under a CC-BY-NC-ND 4.0 International license.

Table 2. Neurocognitive function test at baseline and changes from baseline at four and six months *

\begin{tabular}{llll}
\hline & HA-WBRT & Conformal WBRT & $p$-value \\
\hline Baseline neurocognitive function & & \\
\hline & $N=33$ & $N=32$ & \\
HVLT-R Total Recall & $18.61(16.98$ to 20.33$)$ & $19.00(17.11$ to 20.89$)$ & 0.754 \\
HVLT-R Delayed Recall & $5.88(4.86$ to 6.80$)$ & $6.06(5.06$ to 7.06$)$ & 0.794 \\
HVLT-R Recognition Index & $10.30(9.48$ to 11.12$)$ & $10.47(9.87$ to 11.07$)$ & 0.742 \\
TMT-A & $49.52(42.55$ to 56.50$)$ & $54.28(39.51$ to 69.05$)$ & 0.551 \\
TMT-B & $79.18(68.89$ to 89.48$)$ & $86.59(63.55$ to 109.64$)$ & 0.547 \\
COWA & $18.73(16.49$ to 20.97$)$ & $17.10(14.44$ to 19.75$)$ & 0.340 \\
\hline
\end{tabular}

Changes from baseline to four months after WBRT

\begin{tabular}{llll}
\hline & $N=25$ & $N=24$ & \\
HVLT-R Total Recall & $+0.84(-1.68$ to +3.36$)$ & $+1.67(-0.73$ to +4.06$)$ & 0.626 \\
HVLT-R Delayed Recall & $-0.52(-1.62$ to +0.58$)$ & $+0.25(-0.86$ to +1.36$)$ & 0.313 \\
HVLT-R Recognition Index & $-1.72(-3.32$ to -0.12$)$ & $-0.96(-1.83$ to -0.09$)$ & 0.392 \\
TMT-A & $+15.67(-4.77$ to +36.11$)$ & $+1.56(-3.30$ to +6.41$)$ & 0.177 \\
TMT-B & $+24.36(-2.89$ to +51.61$)$ & $+9.71(-8.40$ to 27.83$)$ & 0.361 \\
COWA & $-0.48(-2.87$ to +1.91$)$ & $+1.65(-0.81$ to +4.12$)$ & 0.205 \\
\hline Changes from baseline to six months after WBRT & & \\
\hline & $N=17$ & $N=20$ & \\
HVLT-R Total Recall & $+1.65(-1.68$ to +3.36$)$ & $-0.95(-2.75$ to +0.85$)$ & $\mathbf{0 . 0 7 9}$ \\
HVLT-R Delayed Recall & $+0.35(-0.74$ to +1.44$)$ & $-0.65(-1.64$ to +0.34$)$ & 0.160 \\
HVLT-R Recognition Index & $+0.53(-0.49$ to 1.54$)$ & $-1.25(-2.39$ to -0.12$)$ & $\mathbf{0 . 0 1 9}$ \\
TMT-A & $-0.53(-12.57$ to +11.51$)$ & $+4.10(-5.38$ to +13.58$)$ & 0.528 \\
TMT-B & $-3.18(-22.47$ to +16.12$)$ & $+9.15(-14.41$ to +32.71$)$ & 0.400 \\
COWA & $+1.47(-1.35$ to +4.29$)$ & $+1.00(-2.18$ to +4.18$)$ & 0.817 \\
\hline
\end{tabular}

Abbreviations: $N$, numbers; HA-WBRT, hippocampal avoidance whole brain radiotherapy; WBRT, whole brain radiotherapy; HVLT-R, Hopkins Verbal Learning Test-Revised; TMT, Trail Making Test; COWA, Controlled Oral Word Association Test.

* Raw scores (HVLT-R), time (TMT-A/B), and word counts (COWA) were recorded, and all the tests were done in Mandarin version. Data are presented as mean values plus lower and upper limit of $95 \%$ confidence interval. 